\title{
Biosurfactant Producing Bacteria from Oil Contaminated Egyptian Soil
}

\author{
E. M. Ramadan, Zeinb M. Kheiralla ${ }^{*}$, M. A. Foaad ${ }^{* *}$, T. S. \\ EL-Tayeb and Eman Z. Goma** \\ Department of Agricultural Microbiology, Faculty of \\ Agriculture, Ain Shams University, Shoubra El-Kheima; \\ *Department of Microbiology, Faculty of Woman for Arts, \\ Science \& Education, Ain Shams University, Heliopolis and \\ ** Department of Biological Sciences \& Geology, Faculty of \\ Education, Ain Shams University, Heliopolis, Cairo, Egypt.
}

\begin{abstract}
TEN PURE bacterial isolates with biosurfactant activity were obtained from autochthonous microflora of oil contaminated soil. Soil samples were selected from bus garage stations in Cairo and from different plots around oil wells of western desert of Egypt. Biosurfactant production was investigated using three parameters (hydrolyses of blood, surface tension reduction and emulsification index techniques). The biosurfactant accumulation was coincided with growth. By means of standard bacterial identification procedures, the isolates were identified as different strains of Bacillus licheniformis. The phylogenetic relationships between these strains were determined using the RAPDPCR technique. The similarity between the strains was ranging from 78 to $100 \%$.
\end{abstract}

Keywords: Biosurfactant, Emulsification, Bacillus licheniformis, RAPD-PCR.

Pollution of sewage with oil spills from car stations and from oil used as fuels in factories has been a big problem in recent years. Microorganisms synthesize a wide variety of high and low-molecular-mass surfactants (Rosenberg \& Ron, 1997; Richter et al., 1998 and Rahman et al., 2002). Microbial surfactants are a diverse group of surface-active molecules with potential commercial applications in the detergent industry (Rosenberg \& Ron, 1998, 1999), in formulations of herbicides and pesticides (Rubinovitz et al., 1982 and Patel \& Gopinathan, 1986), in the petroleum, pharmaceutical and food processing industries. Potentially they can be manufactured from renewable and cheaper substrates (Maier \& SoberonChavez, 2000; La Duc et al., 2004 and Cameotra \& Makkar, 2004).

Biosurfactants have unique amphipathic properties derived from their complex structures, which have both hydrophilic and hydrophobic domains. The lipopeptides and glycoproteins are interesting classes of microbial surfactants (Cameotra \& Makkar, 1998 and Walzer et al., 2006) because of their manifold attractive properties. Biosurfactants produced by hydrocarbon-degrading 
microorganisms can emulsify hydrocarbon-water mixtures, which enables them to grow on the oil droplets. These emulsification properties have also been demonstrated to enhance hydrocarbon degradation in the environment, making them potential tools for oil spill pollution-control (Banat, 1995). Biosurfactants are used for soil washing or flushing due to their ability to mobilize contaminants (Lin, 1996). They can be potentially as effective as highly used synthetic surfactants and they have some distinct advantages, including high specificity, biodegradability and biocompatibility (Kanga et al., 1997).

Genomic fingerprinting assays using random amplified polymorphic DNA polymerase chain reaction (RAPD-PCR) had been detected as excellent methodologies and are fast and sensitive means for identifying small differences between similar complex genomes. Molecular genetic markers have been developed into powerful tools to analyze genetic relationships and genetic diversity. Main advantages of the RAPD-PCR technology include (i) Suitability for work on anonymous genomes, (ii) Applicability to problems where only limited quantities of DNA are available, (iii) Efficiency and low expense (Hadrys et al., 1992).

The present work isolated local bacterial biosurfactant producing strains from oil contaminated soil, examined their production of biosurfactant and assessed the similarity between them depending on the genomic differences.

\section{Materials and Methods}

\section{Isolation of biosurfactant-producing bacteria}

The bacterial strains were isolated from microflora present in oil slurrycontaminated soil from five different bus garage stations in Cairo and from different plots around oil wells of western desert of Egypt according to the procedure of Van Elsas \& Smalla (1997). Five grams of each soil sample were placed into $250 \mathrm{ml}$ Erlenmeyer flasks containing $50 \mathrm{ml}$ of sterilized tap water and incubated at $30^{\circ} \mathrm{C} \pm 2^{\circ} \mathrm{C}$ on a shaker at $150 \mathrm{rpm}$ for 21 days. On days $3,7,14$ and 21 , a sample from each soil slurry was serially diluted, plated on PYG agar (Rocha et al., 1992) and incubated for 3 days. After incubation, different slimy, yellowish and white individual colonies were repeatedly sub-cultured on PYG agar medium to obtain single isolates. The developed pure colonies on the plates were then maintained on slants of the same medium for biosurfactant production screening. Purified culture slants were kept at $4^{\circ} \mathrm{C}$ and transferred at regular intervals.

\section{Growth conditions for biosurfactant production}

For biosurfactant production, bacterial isolates were grown aerobically on minimal salt medium (Deziel et al., 1996) with the following composition (g/l): $\mathrm{MgSO}_{4} .7 \mathrm{H}_{2} \mathrm{O}, 0.2 ; \mathrm{CaCl}_{2} .2 \mathrm{H}_{2} \mathrm{O}, 0.02 ; \mathrm{KH}_{2} \mathrm{PO}_{4}, 1 ; \mathrm{K}_{2} \mathrm{HPO}_{4}, 1 ;\left(\mathrm{NH}_{4}\right)_{2} \mathrm{SO}_{4}, 1 ; \mathrm{FeCl}_{3}$, $0.05 ; \mathrm{pH}, 7.0$. Crude oil (the sole carbon source) was added to the sterilized medium at $0.5 \%$ v/v. Crude oil was obtained from Ennpi Petroleum Company, Nasr City, Cairo, Egypt. Twenty $\mathrm{ml}$ of the standard inoculum $\left(5 \times 10^{7}\right.$ cell $\left./ \mathrm{ml}\right)$ were introduced into triplicate sets of 21 Erlenmeyer flasks containing $800 \mathrm{ml}$ of medium with shaking at $200 \mathrm{rpm}$ in a shaking incubator at $30^{\circ} \mathrm{C} \pm 2^{\circ} \mathrm{C}$.

Egypt. J. Microbiol. 45 (2010) 


\section{Screening of biosurfactant-producing bacteria}

Thirty different isolates were tested for their ability to produce biosurfactant according to the conditions described before. The preliminary investigation of biosurfactant production was detected after 12 days of incubation by using three parameters: the formation of a clear zone on blood agar plates (Morikawa et al., 1993), surface tension reduction (Verma et al., 2006) and by the emulsification index technique (Patel \& Desai, 1997).

\section{Identification of bacteria}

The bacterial cultures which gave the highest biosurfactant activity were identified by the API 50CH kit system (BioMérieux, Nürtingen, Germany) and analyzed by applying APILAB PLUS 3.3.3 software (Waldeck et al., 2006).

Time course of biomass production and biosurfactant accumulation

The most efficient biosurfactant-producing strains were grown under the conditions described before. Dry biomass weight was used for monitoring the growth of bacteria according to the method described by Sifour et al. (2005). The bacterial growth and emulsion index $\%$ as the indicator of biosurfactant production (Verma et al., 2006) were determined throughout 12 days of incubation.

\section{DNA extraction and RAPD-PCR analysis}

One loop of each bacterial isolate was inoculated into $50 \mathrm{ml}$ of nutrient broth PYG medium in $250 \mathrm{ml}$ Erlenmeyer flasks and incubated at $30^{\circ} \mathrm{C}$ with shaking at $150 \mathrm{rpm}$ for $48 \mathrm{hr}$. After incubation, cells were separated by centrifugation at $10,000 \times g$ for $30 \mathrm{~min}$. One gram fresh biomass of each bacterial strain was used for DNA extraction as described by Dellaporta et al. (1983). Five random primers were applied for PCR reaction according to Williams et al. (1990). List of primers and their corresponding nucleotide sequences were as the following: OP-11, 5'-GAC AGG AGG T -3'; OP-13, 5'-GTC AGA GTC C -3'; OP-14, 5'-AGC ATG GCT C -3'; OP-15, 5'-TGG CGT CCT T - $3^{\prime}$; OP-17, 5'-GGC TTA TGC C - $3^{\prime}$. Twelve $\mu$ l of DNA amplified product of each positive producer strain were loaded on each well and run at 75 voltage for about (45-75) min at room temperature. The bands were scanned using Gel Doc-2001 BioRad system. The gels of DNA were visualized and photographed by gel documentation system (Gel-Doc Bio-Rad 2000) under UV transilluminator. RAPD patterns were calculated according to the method of Sambrook et al. (1989) by using RAPD distance software package, version 1.04 (Armstrong et al., 1994).

\section{Results and discussion}

Isolation, identification and screening of biosurfactant-producing bacteria

Different oil-contaminated soil samples with different degrees of oil contamination were collected in order to isolate biosurfactant-producing bacteria. Thirty different bacterial colonies were isolated from soil samples polluted with oil. The preliminary investigation showed that only ten isolates produced relatively active biosurfactant on mineral basal medium containing $0.5 \% \mathrm{v} / \mathrm{v}$ crude oil, detected by the formation of clear zone on blood agar, by measuring the emulsion index and surface tension reduction assays (Table 1). The biosurfactant-producing isolates were 
identified as different strains of Bacillus licheniformis. The strains that showed high hemolytic activity reduced by good means the surface tension of the medium comparing with the control (uninoculated medium). B. licheniformis str. No. 4, 5 and 6 were preceding in most of the biosurfactant production markers. The surface tension of the medium was reduced from 63.85 to $50.31,47.08$ and $49.02 \mathrm{mN} / \mathrm{m}$ by $B$. licheniformis str. No. 4, 5 and 6, respectively. Correlation coefficient at $\mathrm{p}<0.05$ indicated a moderate positive correlation (substantial relationship) between the growth of the strains and hemolytic activity (0.478). In addition, high positive correlations (marked relationship) between the growth and emulsion index (0.858) was recorded. However, a high negative correlation $(-0.866)$ was recorded between the growth of the strains and surface tension measurements. It means that the hemolytic and emulsification activities were enhanced as the growth increased, while the surface tension decreased.

TABLE 1. Screening of different strains of $B$. licheniformis for growth and biosurfactant production after 12 days of incubation at $30^{\circ} \mathrm{C} \pm 2^{\circ} \mathrm{C}$.

\begin{tabular}{|c|c|c|c|c|}
\hline \multirow[b]{2}{*}{$\begin{array}{c}\text { Bacterial } \\
\text { strains }\end{array}$} & \multirow[b]{2}{*}{$\begin{array}{c}\text { Cell dry } \\
\text { weight } \\
(\mathrm{g} / \mathrm{l})\end{array}$} & \multicolumn{3}{|c|}{ Biosurfactant production } \\
\hline & & $\begin{array}{l}\text { Hemolytic } \\
\text { clear zone } \\
\quad(\mathrm{cm})\end{array}$ & $\begin{array}{c}\text { Surface } \\
\text { tension } \\
(\mathrm{mN} / \mathrm{m})\end{array}$ & $\begin{array}{c}\text { Emulsion } \\
\text { Index } \\
\left(\mathbf{E}_{24} \%\right)\end{array}$ \\
\hline Bacillus licheniformis str. No. 1 & $0.164 \pm 0.00$ & $2.8 \pm 0.10$ & $55.12 \pm 0.05$ & $1.52 \pm 0.03$ \\
\hline Bacillus licheniformis str. No. 2 & $0.203 \pm 0.01$ & $2.7 \pm 0.15$ & $55.33 \pm 0.01$ & $1.82 \pm 0.03$ \\
\hline Bacillus licheniformis str. No. 3 & $0.196 \pm 0.00$ & $3.2 \pm 0.16$ & $55.35 \pm 0.03$ & $1.85 \pm 0.02$ \\
\hline Bacillus licheniformis str. No. 4 & $0.852 \pm 0.03$ & $3.3 \pm 0.20$ & $50.31 \pm 0.02$ & $8.33 \pm 1.82$ \\
\hline Bacillus licheniformis str. No. 5 & $0.641 \pm 0.04$ & $4.4 \pm 0.39$ & $47.08 \pm 0.04$ & $12.72 \pm 1.95$ \\
\hline Bacillus licheniformis str. No. 6 & $0.590 \pm 0.07$ & $3.8 \pm 0.13$ & $49.02 \pm 0.04$ & $11.16 \pm 0.79$ \\
\hline Bacillus licheniformis str. No. 7 & $0.266 \pm 0.01$ & $1.5 \pm 0.11$ & $55.40 \pm 0.06$ & $1.87 \pm 0.02$ \\
\hline Bacillus licheniformis str. No. 8 & $0.310 \pm 0.01$ & $2.5 \pm 0.06$ & $54.90 \pm 0.01$ & $3.05 \pm 0.062$ \\
\hline Bacillus licheniformis str. No. 9 & $0.357 \pm 0.00$ & $3.2 \pm 0.53$ & $53.53 \pm 0.02$ & $5.10 \pm 0.67$ \\
\hline Bacillus licheniformis str. No. 10 & $0.284 \pm 0.01$ & $2.7 \pm 0.24$ & $54.22 \pm 0.00$ & $3.75 \pm 0.02$ \\
\hline
\end{tabular}

Results are expressed as the means \pm standard error of three replicates.

The spreading of bacteria in the soil contaminated with oil has been explained on the basis of the adaptation of the strains to the oil contaminated soil/liquid environment (Sugiura et al., 1997 and Rahman et al., 2003). Furthermore, Ijah \& Antai (2003) reported that Bacillus spp. were predominant among the crude oil utilizing bacteria in soil contaminated with $30-40 \%$ crude oil. They also found that, among five strains compared, Bacillus sp. was most effective. Likewise, Ghazali et al. (2004) postulated that Bacillus spp. were more tolerant to high levels of hydrocarbons in soil owing to their resistant endospores. In this work, thirty different bacterial colonies were isolated from oil-contaminated soil samples with different degrees of oil contamination. The choice of localities for soil sampling was because the microbial communities in these contaminated samples are expected to produce

Egypt. J. Microbiol. 45 (2010) 
biosurfactant (Lin, 1996). The hemolytic activity was regarded by many authors as an indicative biomarker for the biosurfactant production and used as a rapid method for bacterial screening (Banat, 1995 and Lin, 1996). In a similar study, Rismani et al. (2006) used such method to detect the biosurfactant production by B. licheniformis isolated from the Persian Gulf. Although the hemolytic activity has been reported as an initial criterion for biosurfactant producers, other more conclusive tests such as surface tension measurement were carried out for confirmation of the obtained results. The reduction of surface tension may be due to the biosurfactant availability. It was reported that the growth of microorganisms on hydrocarbon containing medium is limited by a decrease of interfacial tension and increase in the degree of medium emulsification as a critical factor (Palittapongarnpim et al., 1998). The differences in emulsifying activity of the isolated $B$. licheniformis strains may be related to the hypothesis of that a minor variation in biosurfactant isoforms produced by these strains might result in a large variation of the emulsification property (Das \& Mukherjee, 2007).

Time course of biomass production and biosurfactant accumulation

This experiment was carried out to monitor the growth and biosurfactant biosynthesis by the most efficient strains of B. licheniformis throughout 12 days of incubation period. Chosen bacterial strains proved to grow on oil slurry in addition to produce the biosurfactant which was strain dependent (Fig. 1, 2). $B$. licheniformis str. No. 4, 5 and 6 grew slowly during the twelve days of incubation. The most growth $(0.929 \mathrm{~g} / \mathrm{l})$ was obtained after eight days of incubation by $B$. licheniformis str. No. 4 . The most growth of $B$. licheniformis str. No. 5 and 6 were 0.729 and 0.698 g/l, respectively after 9 days. These results were consistent with biosurfactant production. B. licheniformis str. No. 4 and 6 attained their highest emulsification indexes after 7 days of incubation $(8.48 \%$, $11.5 \%$, respectively), while, $B$. licheniformis str. No. 5 attained its highest emulsification index $(15.12 \%)$ after 9 days of incubation.

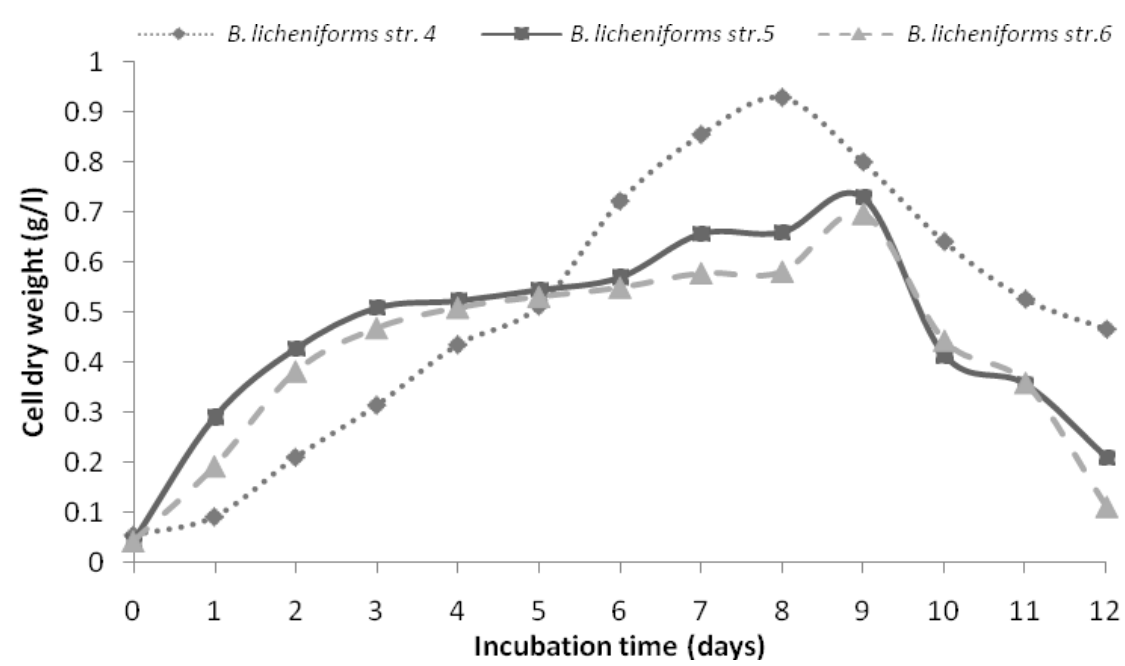

Fig. 1. Time course of biomass production by the most biosurfactant-producing strains of $B$. licheniformis.

Egypt. J. Microbiol. 45 (2010) 


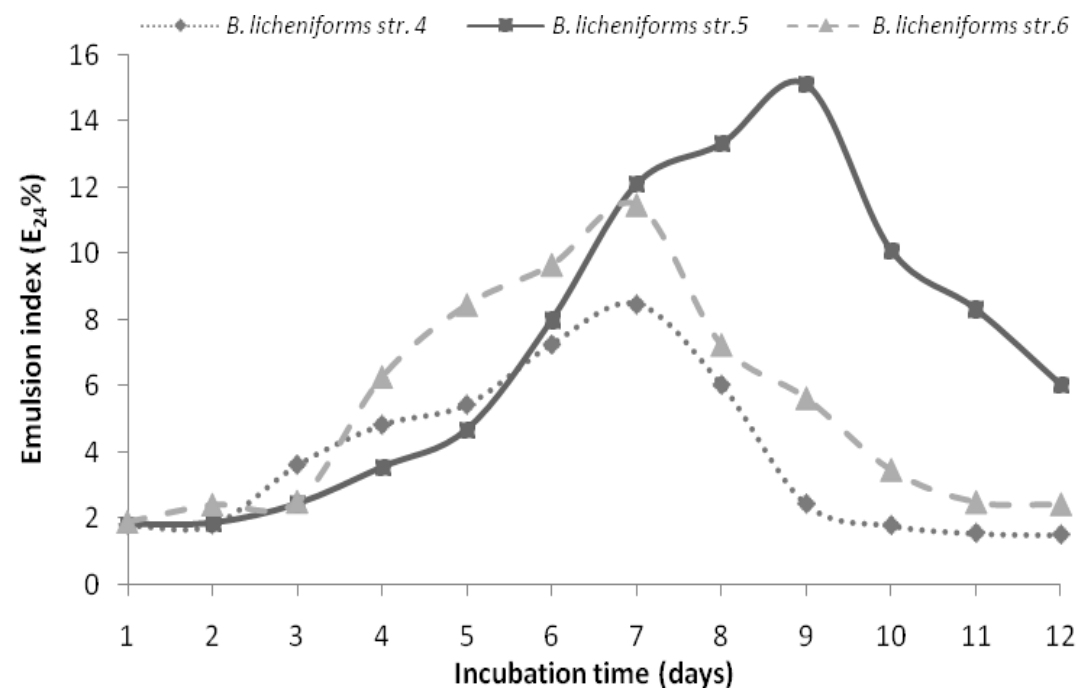

Fig. 2. Time course of biosurfactant accumulation by the most biosurfactantproducing strains of $B$. licheniformis.

RAPD-PCR analysis

The RAPD-PCR of $B$. licheniformis strains produced bands which ranged in sizes of 236 to $1284 \mathrm{bp}$. The results in Fig. 3 and Table 2 showed that the number of amplified fragments differed with different primers. Also, the number and sizes of amplified fragments differed from one strain to another for the same primer. The number of bands for each primer varied from 3 to 9 . The results of primer OP-11 indicated the production of two monomorphic bands with 729 and $626 \mathrm{bp}$ and one polymorphic band (shared) with 500 bp that present in all strains except isolate No.10. Primer OP-13 resulted in the appearance of four monomorphic bands with 477, 410, 365 and 287 bp. Five polymorphic bands were scored. One of them was genotype specific band of isolate No. 9 with 745 bp. The results of primer OP-14 indicated the presence of two monomorphic bands (with 853 and $430 \mathrm{bp}$ ) and five polymorphic bands. Two bands of 717 and 558 bp were present in all strains except No. 1, 2 and 3. On the other hand, two bands with 688 and 526 bp were present only in isolate No. 1 , 2 and 3 and absent in other strains. Only band with 329 bp was present in all strains except isolate No.10. There are two monomorphic bands (with 786 and 566 bp) and only one polymorphic band (with 696 bp which was present in all strains except No. 5) was scored in primer OP-15. Primer OP-17 resulted in the production of only four monomorphic bands with 1284, 1122, 892 and $685 \mathrm{bp}$. No polymorphic bands were observed using this primer. The results presented in Table 3 indicated that a total number of twenty six amplified fragments were obtained, out of which fourteen were monomorphic bands, eleven were shared bands and only one unique band was presented by using primer OP-13. The similarity between the ten strains of $B$. licheniformis was ranging from 78 to $100 \%$ (Table 4). Clustering of all strains was determined and the results of phylophenetic tree were given in Fig 4. The data indicated the presence of two major related clusters (A, B). Cluster A included $B$.

Egypt. J. Microbiol. 45 (2010) 
licheniformis str. No. 1, 2 and 3 and cluster B included B. licheniformis str. No. 4, 5, 6, 7, 8, 9 and 10. Cluster A contained two sub clusters. B. licheniformis str. No.1 placed in one sub cluster with a similarity of 90.5 and $92.7 \%$ to B. licheniformis str. No.2 and No. 3, respectively. The other sub cluster included B. licheniformis str. No. 2 and 3 with a similarity degree of $97.8 \%$. Cluster B contained two sub clusters. $B$. licheniformis strain No.10 fell in one sub cluster with similarity of $90 \%$ to $B$. licheniformis str. No. 4 \& 6; and an $87.2 \%$ with $B$. licheniformis str. No. 5, 7; and $92.3 \& 87.8 \%$ with $B$. licheniformis str. No. $8 \& 9$, respectively. The other sub cluster contained $B$. licheniformis str. No. 4, 5, 6, 7, 8 and 9. The similarity between $B$. licheniformis str. No. 4 and 6 reached 100\%. The degree of similarity was comparatively low among most of the strains, showing that there is a large degree of heterogeneity among some of these local strains.
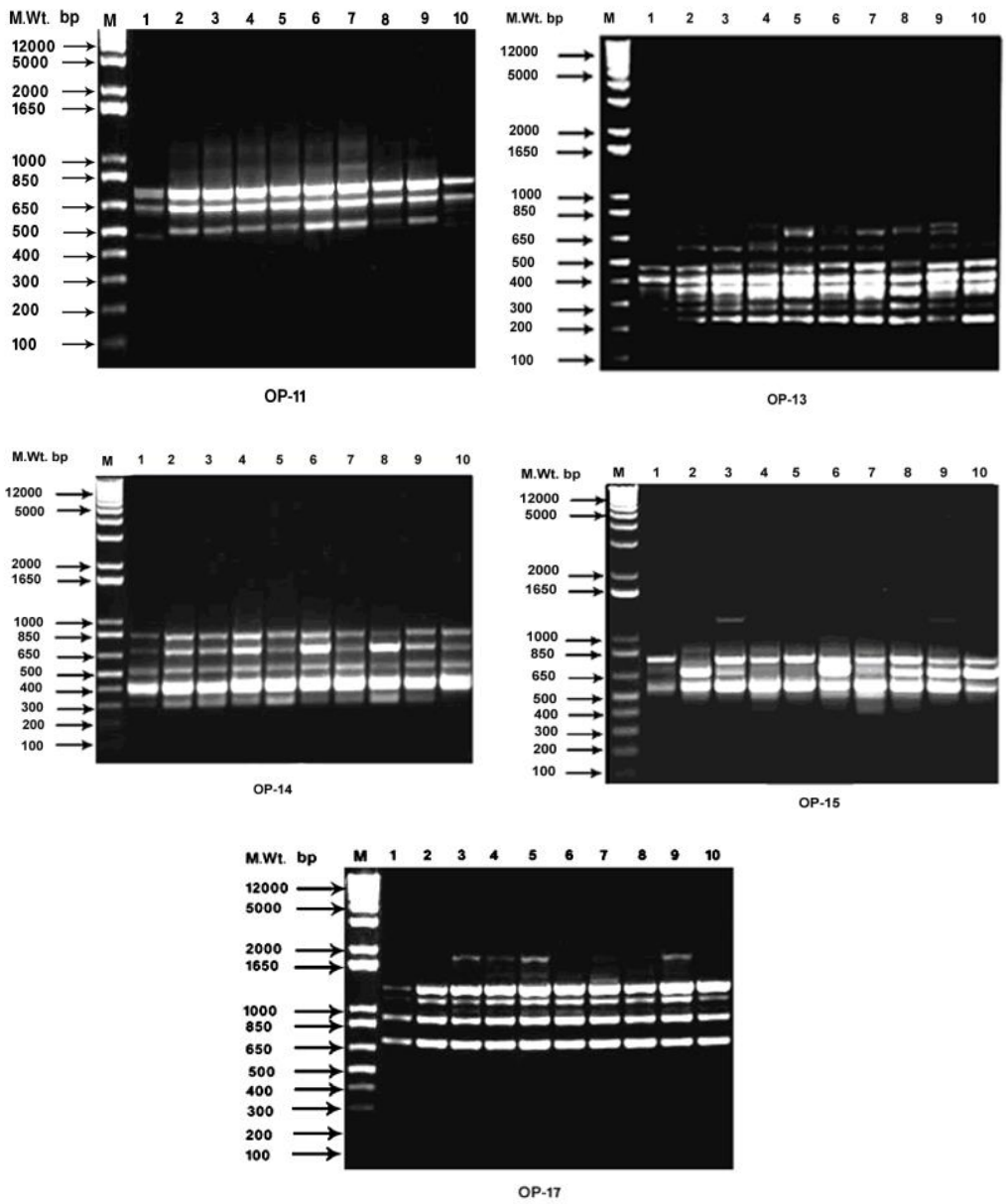

M=marker

1-10= B. licheniformis strains

Fig. 3. 1.2\% agarose gel electrophoresis show DNA polymorphisms of RAPD-PCR analysis of ten $B$. licheniformis strains (Lanes 1-10) using OP-11, OP-13, OP14, OP-15 and OP-17 primers. 
TABLE 2. DNA polymorphism of $B$. licheniformis strains amplified with OP-11, OP13, OP-14, OP-15 and OP-17 primers.

\begin{tabular}{|c|c|c|c|c|c|c|c|c|c|c|c|c|}
\hline \multirow{2}{*}{$\begin{array}{c}\text { Primer's } \\
\text { name }\end{array}$} & \multirow[b]{2}{*}{ No. } & \multirow{2}{*}{$\begin{array}{c}\text { M. } \\
\text { Size } \\
\text { (bp) }\end{array}$} & \multicolumn{10}{|c|}{ Bacillus licheniformis strains } \\
\hline & & & 1 & 2 & 3 & 4 & 5 & 6 & 7 & 8 & 9 & 10 \\
\hline \multirow{4}{*}{$\begin{array}{l}\bar{\prime} \\
\overline{0}\end{array}$} & 1 & 729 & 1 & 1 & 1 & 1 & 1 & 1 & 1 & 1 & 1 & 1 \\
\hline & 2 & 626 & 1 & 1 & 1 & 1 & 1 & 1 & 1 & 1 & 1 & 1 \\
\hline & 3 & 500 & 1 & 1 & 1 & 1 & 1 & 1 & 1 & 1 & 1 & 0 \\
\hline & \multicolumn{2}{|l|}{ Total } & 3 & 3 & 3 & 3 & 3 & 3 & 3 & 3 & 3 & 2 \\
\hline \multirow{10}{*}{$\begin{array}{l}\frac{m}{0} \\
\frac{1}{0}\end{array}$} & 1 & 745 & 0 & 0 & 0 & 0 & 0 & 0 & 0 & 0 & 1 & 0 \\
\hline & 2 & 689 & 0 & 1 & 0 & 1 & 1 & 1 & 1 & 1 & 1 & 0 \\
\hline & 3 & 589 & 0 & 1 & 1 & 1 & 1 & 1 & 1 & 0 & 1 & 0 \\
\hline & 4 & 477 & 1 & 1 & 1 & 1 & 1 & 1 & 1 & 1 & 1 & 1 \\
\hline & 5 & 410 & 1 & 1 & 1 & 1 & 1 & 1 & 1 & 1 & 1 & 1 \\
\hline & 6 & 365 & 1 & 1 & 1 & 1 & 1 & 1 & 1 & 1 & 1 & 1 \\
\hline & 7 & 326 & 0 & 1 & 1 & 0 & 0 & 0 & 0 & 0 & 0 & 0 \\
\hline & 8 & 287 & 1 & 1 & 1 & 1 & 1 & 1 & 1 & 1 & 1 & 1 \\
\hline & 9 & 236 & 0 & 1 & 1 & 1 & 1 & 1 & 1 & 1 & 1 & 1 \\
\hline & \multicolumn{2}{|l|}{ Total } & 4 & 8 & 7 & 7 & 7 & 7 & 7 & 6 & 8 & 5 \\
\hline \multirow{8}{*}{$\begin{array}{l}\frac{ \pm}{1} \\
0^{\prime}\end{array}$} & 1 & 853 & 1 & 1 & 1 & 1 & 1 & 1 & 1 & 1 & 1 & 1 \\
\hline & 2 & 717 & 0 & 0 & 0 & 1 & 1 & 1 & 1 & 1 & 1 & 1 \\
\hline & 3 & 688 & 1 & 1 & 1 & 0 & 0 & 0 & 0 & 0 & 0 & 0 \\
\hline & 4 & 558 & 0 & 0 & 0 & 1 & 1 & 1 & 1 & 1 & 1 & 1 \\
\hline & 5 & 526 & 1 & 1 & 1 & 0 & 0 & 0 & 0 & 0 & 0 & 0 \\
\hline & 6 & 430 & 1 & 1 & 1 & 1 & 1 & 1 & 1 & 1 & 1 & 1 \\
\hline & 7 & 329 & 1 & 1 & 1 & 1 & 1 & 1 & 1 & 1 & 1 & 0 \\
\hline & \multicolumn{2}{|l|}{ Total } & 5 & 5 & 5 & 5 & 5 & 5 & 5 & 5 & 5 & 4 \\
\hline \multirow{4}{*}{$\frac{n}{\frac{n}{1}}$} & 1 & 786 & 1 & 1 & 1 & 1 & 1 & 1 & 1 & 1 & 1 & 1 \\
\hline & 2 & 696 & 1 & 1 & 1 & 1 & 0 & 1 & 1 & 1 & 1 & 1 \\
\hline & 3 & 566 & 1 & 1 & 1 & 1 & 1 & 1 & 1 & 1 & 1 & 1 \\
\hline & \multicolumn{2}{|l|}{ Total } & 3 & 3 & 3 & 3 & 2 & 3 & 3 & 3 & 3 & 3 \\
\hline \multirow{5}{*}{$\frac{1}{0}$} & 1 & 1284 & 1 & 1 & 1 & 1 & 1 & 1 & 1 & 1 & 1 & 1 \\
\hline & 2 & 1122 & 1 & 1 & 1 & 1 & 1 & 1 & 1 & 1 & 1 & 1 \\
\hline & 3 & 892 & 1 & 1 & 1 & 1 & 1 & 1 & 1 & 1 & 1 & 1 \\
\hline & 4 & 685 & 1 & 1 & 1 & 1 & 1 & 1 & 1 & 1 & 1 & 1 \\
\hline & Total & & 4 & 4 & 4 & 4 & 4 & 4 & 4 & 4 & 4 & 4 \\
\hline \multicolumn{3}{|c|}{ Total No. of bands } & 19 & 23 & 22 & 22 & 21 & 22 & 22 & 21 & 23 & 18 \\
\hline
\end{tabular}


TABLE 3. Number and types of amplified DNA bands as well as the percentage of the total polymorphism generated by five primers of $B$. licheniformis strains.

\begin{tabular}{|c|c|c|c|c|c|}
\hline \multirow{2}{*}{$\begin{array}{c}\text { Primer } \\
\text { code }\end{array}$} & \multirow{2}{*}{$\begin{array}{c}\text { Monomorphic } \\
\text { bands }\end{array}$} & \multicolumn{2}{|c|}{$\begin{array}{c}\text { Polymorphic bands } \\
\text { Shared } \\
\text { bands }\end{array}$} & $\begin{array}{c}\text { Unique } \\
\text { bands }\end{array}$ & \multirow{2}{*}{ Total } \\
bands & $\begin{array}{c}\text { Polymorphism } \\
\%\end{array}$ \\
\hline OP-11 & 2 & 1 & - & 3 & $33.3 \%$ \\
\hline OP-13 & 4 & 4 & 1 & 9 & $55.5 \%$ \\
\hline OP-14 & 2 & 5 & - & 7 & $71.4 \%$ \\
\hline OP-15 & 2 & 1 & - & 3 & $33.3 \%$ \\
\hline OP-17 & 4 & - & - & 4 & $0 \%$ \\
\hline $\begin{array}{c}\text { Total No. of } \\
\text { bands }\end{array}$ & 14 & 11 & 1 & 26 & - \\
\hline
\end{tabular}

TABLE 4. Percentage of phylogenetic relationship between $B$. licheniformis strains based on RAPD-PCR analysis using 5 primers.

\begin{tabular}{|l|l|l|l|l|l|l|l|l|l|l|}
\hline $\begin{array}{c}\text { Bacillus } \\
\text { licheniformis } \\
\text { strains }\end{array}$ & $\begin{array}{c}\text { str. } \\
\text { No. } \\
\mathbf{1}\end{array}$ & $\begin{array}{c}\text { str. } \\
\text { No. }\end{array}$ & $\begin{array}{c}\text { str. } \\
\text { No. } \\
\mathbf{3}\end{array}$ & $\begin{array}{c}\text { str. } \\
\text { No. } \\
\mathbf{4}\end{array}$ & $\begin{array}{c}\text { str. } \\
\text { No. } \\
\mathbf{5}\end{array}$ & $\begin{array}{c}\text { str. } \\
\text { No. } \\
\mathbf{6}\end{array}$ & $\begin{array}{c}\text { str. } \\
\text { No. } \\
\mathbf{7}\end{array}$ & $\begin{array}{c}\text { str. } \\
\text { No. } \\
\mathbf{8}\end{array}$ & $\begin{array}{c}\text { str. } \\
\text { No. } \\
\mathbf{9}\end{array}$ & $\begin{array}{c}\text { str. } \\
\text { No. } \\
\mathbf{1 0}\end{array}$ \\
\hline str. No. 1 & 100 & & & & & & & & & \\
\hline str. No. 2 & 90.5 & 100 & & & & & & & & \\
\hline str. No. 3 & 92.7 & 97.8 & 100 & & & & & & & \\
\hline str. No. 4 & 82.9 & 88.9 & 86.4 & 100 & & & & & & \\
\hline str. No. 5 & 80 & 86.4 & 83.7 & 97.7 & 100 & & & & & \\
\hline str. No. 6 & 82.9 & 88.9 & 86.4 & 100 & 97.7 & 100 & & & & \\
\hline str. No. 7 & 80 & 86.4 & 83.7 & 97.7 & 95.2 & 97.7 & 100 & & & \\
\hline str. No. 8 & 85 & 86.4 & 83.7 & 97.7 & 95.2 & 97.7 & 95.2 & 100 & & \\
\hline str. No. 9 & 81 & 87 & 84.4 & 97.8 & 95.5 & 97.8 & 95.5 & 95.5 & 100 & \\
\hline str. No. 10 & 81.1 & 78 & 80 & 90 & 87.2 & 90 & 87.2 & 92.3 & 87.8 & 100 \\
\hline
\end{tabular}

\section{Conclusions}

The present work confirmed the relationship between the contamination with crude oil and enumeration of the soil with biosurfactant-producing bacteria. The isolated bacteria were able to produce biosurfactant on mineral basal medium containing $0.5 \% \mathrm{v} / \mathrm{v}$ crude oil. The bacterial isolates were identified as different strains of $B$. licheniformis. The similarity between the strains was ranged from 78 to $100 \%$. Further investigations will be carried out to optimize either the nutritional and environmental factors to enhance the production of biosurfactant. 


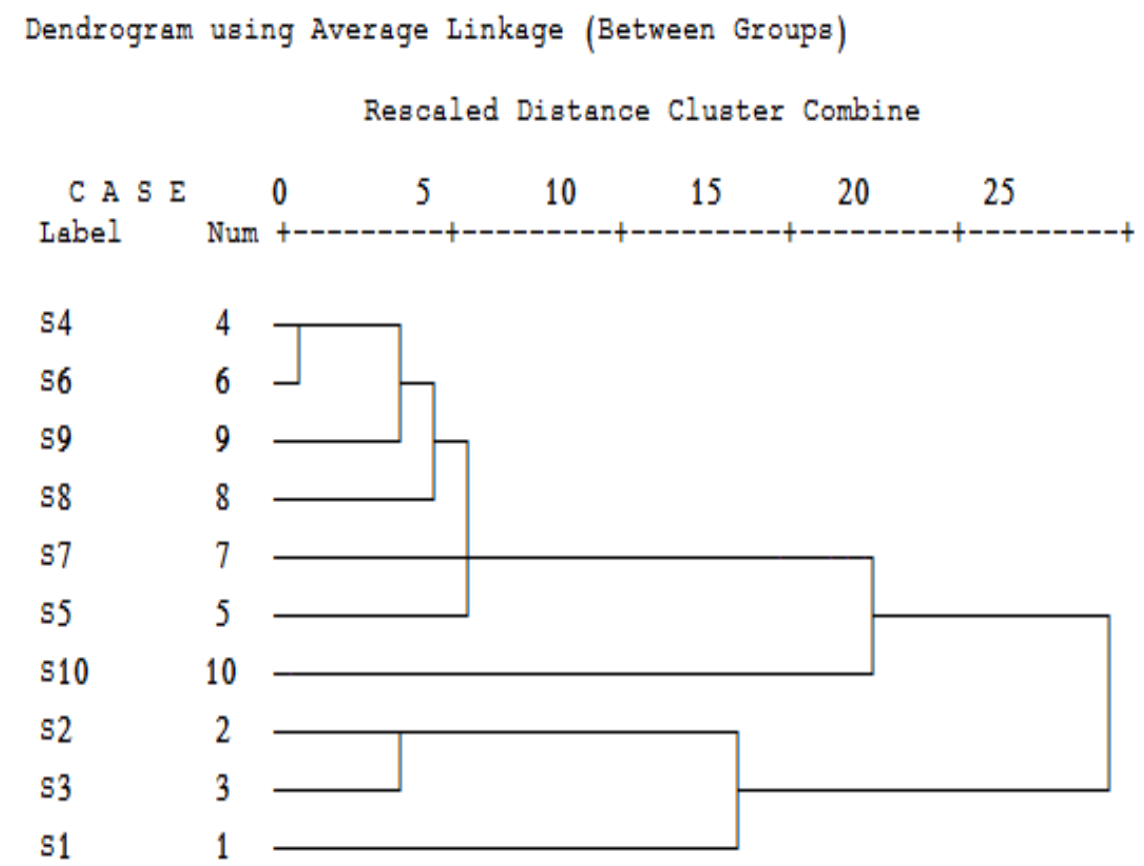

Fig. 4. Phylogenetic tree of $B$. licheniformis strains based on RAPD-PCR analysis using five random primers and by using SPSS13 analysis program, (The number denoted from 1-10 refers to the number of strain).

\section{References}

Armstrong, J.S., Gibbs, A.J., Peakall, R. and Weiller, G. (1994) The RAPD instance Package, version 1.04, http://life.anu.edu.au/molecular/software/rapd.html.

Banat, I.M. (1995) Biosurfactants production and possible uses in microbial enhanced oil recovery and oil pollution remediation. A review. Bioresour. Technol. 51, 1-12.

Cameotra, S.S. and Makkar, R.S. (1998) Synthesis of biosurfactants in extreme conditions. Appl. Microbiol. Biotechnol. 50, 520-529.

Cameotra, S.S. and Makkar, R.S. (2004) Recent applications of biosurfactants as biological and immunological molecules. Curr. Opin. Microbiol. 7, 262-266.

Das, K. and Mukherjee, A.K. (2007) Crude petroleum-oil biodegradation efficiency of Bacillus subtilis and Pseudomonas aeruginosa strains isolated from a petroleum-oil contaminated soil from North-East India. Bioresour. Technol. 98, 1339-1345.

Dellaporta, S.L., Wood, J. and Hicks, J.B. (1983) A plant DNA mini preparation. Version III. Plant Mol. Biol. Rep. 1, 19-21. 
Deziel, E., Paquette, G., Villemur, R., Lepine, F. and Bisaillon, J.G. (1996) Biosurfactant production by a soil Pseudomonas strain growing on polycyclic aromatic hydrocarbons, Appl. Environ. Microbiol. 62, 1908-1912.

Ghazali, F.M., Zaliha, R.N., Rahman, A., Salleh, A.B. and Basri, M. (2004) Biodegradation of hydrocarbons in soil by microbial consortium. Int. Biodeterior. Biodegrad. 54, 61-67.

Hadrys, H., Balick, M. and Schierwater, B. (1992) Applications of random amplified polymorphic DNA (RAPD) in molecular ecology. Mol. Ecol. 1, 55-63.

Ijah, U.J.J., and Antai, S.P. (2003) Removal of Nigerian light crude oil in soil over a 12month period. Int. Biodeterior. Biodegrad. 51, 93-99.

Kanga, S.H., Bonner, J.S., Page, C.A., Mills, M.A. and Autenrieth, R.L. (1997) Solubilization of naphthalene and methyl-substituted naphthalenes from crude oil using biosurfactants. Environ. Sci. Technol. 31, 556-561.

La Duc, M.T., Kern, R. and Venkateswaran, K. (2004) Microbial monitoring of spacecraft and associated environments. Microb. Ecol. 47, 150-158.

Lin, S.C. (1996) Biosurfactant: Recent advances. J. Chem. Technol. Biotechnol. 63, 109120.

Maier, R.M. and Soberon-Chavez, G. (2000) Pseudomonas aeruginosa rhamnolipids: biosynthesis and potential applications. Appl. Microbiol. Biotechnol. 54, 625-633.

Morikawa, M., Daido, H., Takao, T., Murata, S., Shimonishi, Y. and Imanaka, T. (1993) A new lipopeptide biosurfactant produced by Arthrobacter sp. strain MIS38. J. Bacteriol. 175, 6459-6466.

Palittapongarnpim, M., Pokethitiyook, P., Upatham, E.S. and Tangbanluekal, L. (1998) Biodegradation of crude oil by soil microorganisms in the tropic. Biodegrad. 9 , 83-90.

Patel, R.M. and Desai, A.J. (1997) Biosurfactant production by Pseudomonas aeruginosa GS3 from molasses. Lett. Appl. Microbiol. 25, 91-94.

Patel, M.N. and Gopinathan, K.P. (1986) Lysozyme-sensitive bioemulsifier for immiscible organophosphorus pesticides. Appl. Environ. Microbiol. 52, 1224-1226.

Rahman, K.S.M., Banat I.M., Thahira, J., Thayumanavan, T. and Lakshmanaperumalsamy, P. (2002) Bioremediation of gasoline contaminated soil by a bacterial consortium amended with poultry litter, coir-pith and rhaminolipid biosurfactant. Bioresour. Technol. 81, 25-32.

Rahman, K.S.M., Rahman, T.J., Lakshmanaperumalsamy, P., Marchant, R. and Banat, I.M. (2003) The potential of bacterial isolates for emulsification with a range of hydrocarbons. Acta-Biotechnol. 23, 335-345.

Richter, M., Willey, J.M., Sussmuth, R., Jung, G. and Fiedler, H.P. (1998) Streptofactin, a novel biosurfactant with aerial mycelium inducing activity from Streptomyces tendae Tu 901/8c. FEMS Microbiol. Lett. 163,165-171.

Egypt. J. Microbiol. 45 (2010) 
Rismani, E., Fooladi, J. and Ebrahimi, P. (2006) Biosurfactant production in batch culture by a Bacillus licheniformis isolated from the Persian gulf. Pak. J. Biol. Sci. 9, 2498-2502.

Rocha, C., San-Blas, F., San-Blas, G. and Vierma, L. (1992) Biosurfactant production by two isolates of Pseudomonas aeruginosa. World J. Microbiol. Biotechnol. 8, 125-128.

Rosenberg, E. and Ron, E.Z. (1997) Bioemulsans: microbial polymeric emulsifiers. Curr. Opin. Biotechnol. 8, 313-316.

Rosenberg, E. and Ron, E.Z. (1998) Surface active polymers from the genus Acinetobacter. In: "Biopolymers from Renewable Resources". Kaplan, D. L. (Ed.). pp. 281-289. New York, N.Y: Springer.

Rosenberg, E. and Ron, E.Z. (1999) High- and low-molecular-mass microbial surfactants. Appl. Microbiol. Biotechnol. 52, 154-162.

Rubinovitz, C., Gutnick, D.L. and Rosenberg, E. (1982) Emulsan production by Acinetobacter calcoaceticus in the presence of chloramphenicol. J. Bacteriol. 152, 126-132.

Sambrook, J., Fritsch, E.F. and Maniatis, T. (1989) "Molecular Cloning”. Cold Spring Harbor Laboratory Press, Cold Spring Harbor, NY, USA.

Sifour, M., Ouled-Haddar, H. and Aziz, G.M. (2005) Production of biosurfactants from two Bacillus species. Egy. J. Aqua. Res. 31, 142-148.

Sugiura, K., Ishihara, M., Shimauchi, T. and Harayama, S. (1997) Physicochemical properties and biodegradability of crude oil. Environ. Sci. Technol. 31, 45-51.

Van Elsas, J.D. and Smalla, K. (1997) Methods for sampling soil microbes. In: "Manual of Environmental Microbiology”.Hurst, C. J., Knudsen, G. R., McInerney, M. J., Stetzenbach, L.D.; Walter, M.V. (Ed.), pp. 383-390. Washington, D.C. American Society for Microbiology.

Verma, S., Bhargava, R. and Pruthi, V. (2006) Oily sludge degradation by bacteria from Ankleshwar, India. Int. Biodeterior. Biodegrad. 57, 207-213.

Waldeck, J., Daum, Gabriele, Bisping, B. and Meinhardt, F. (2006) Isolation and molecular characterization of chitinase-deficient Bacillus licheniformis strains capable of deproteinization of shrimp shell waste to obtain highly viscous chitin. Appl. Environ. Microbiol. 72, 7879-7885.

Walzer, G., Rosenberg, E. and Ron, E.Z. (2006) The Acinetobacter outer membrane protein A (Omp A) is a secreted emulsifier. Appl. Environ. Microbiol. 8, 1026-32.

Williams, J.G., Kubelik, A.R., Livak, K.J., Rafalski, J.A. and Tingey, S.V. (1990) DNA polymorphisms amplified by arbitrary primers are useful as genetic markers. Nucleic Acids Res. 25, 6531-6535. 


\section{بكتريا انتاج مخفضات التوتر السطحى الحيوية من التربة المصرية الملوثة بزيت البترول}

الثحات محمد رمضان ، زينب محمد خير الله" ، محمد عبد العزيز فؤاد** ، طارق

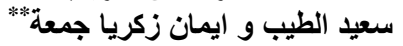

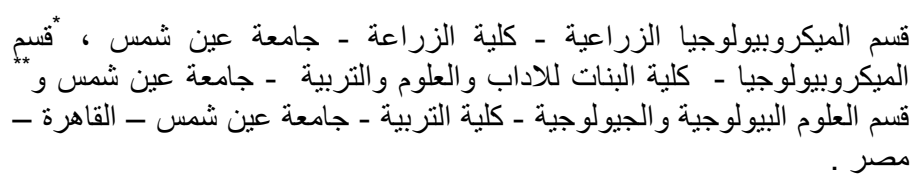

إن مخفضات التوتر السطحى الحيوية هى جزيئات يتم تخليقها بواسطة الكائنات

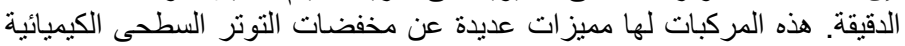

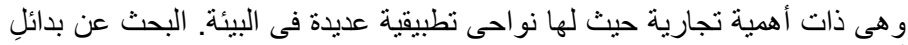

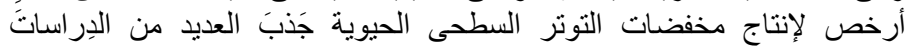

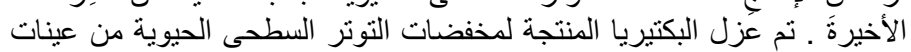

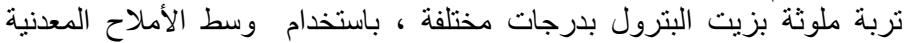

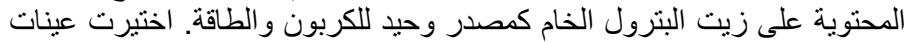

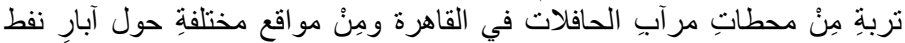

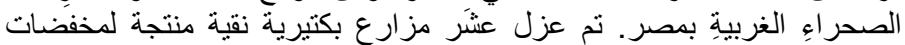

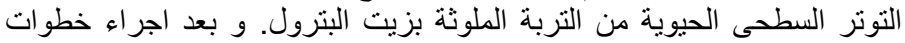

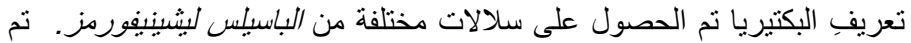

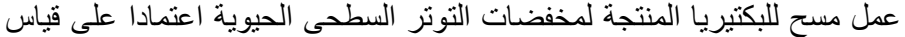

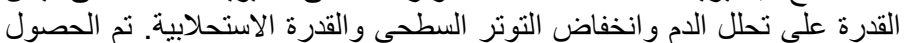

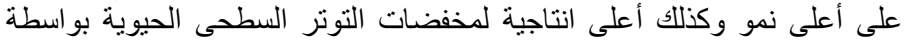

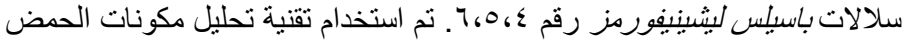

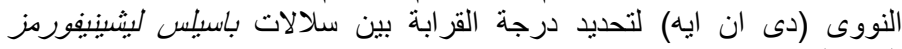
المعزولة الموى 